\title{
Plasmablastic lymphoma in Malawi
}

\author{
Takondwa Zuze ${ }^{1}$, Matthew S. Painschab ${ }^{1,2}$, Ryan Seguin ${ }^{1,2}$, Evarista Kudowa ${ }^{1}$, Bongani Kaimila ${ }^{1}$, \\ Edwards Kasonkanji ${ }^{1}$, Tamiwe Tomoka ${ }^{1,3}$, Bal Mukunda Dhungel ${ }^{1,2}$, Maurice Mulenga ${ }^{4}$, Maria Chikasema ${ }^{1}$, \\ Blessings Tewete ${ }^{1}$, Asekanadziwa Ntangwanika', Sarah Chiyoyola', Fred Chimzimu' ${ }^{1}$ Coxcilly Kampani', \\ Robert Krysiak ${ }^{1,2}$, Nathan D. Montgomery ${ }^{2}$, Yuri Fedoriw ${ }^{2}$ and Satish Gopal ${ }^{1,2,3^{*}}$
}

\begin{abstract}
Plasmablastic lymphoma (PBL) clinical descriptions are scarce from sub-Saharan Africa (SSA) where both HIV and EBV are highly endemic. We identified 12 patients with pathologically confirmed PBL from a prospective cohort in Lilongwe, Malawi. Median age was 46 (range 26-71), seven (58\%) were male, and six (50\%) were HIV-positive. Eight patients were treated with $\mathrm{CHOP}$ and four with a modified EPOCH regimen. One-year overall survival was 56\% (95\% Cl 24-79\%), without clear differences based on HIV status. PBL occurs in Malawi in HIV-positive and HIVnegative individuals and can be treated successfully with curative intent, even in a low-resource setting in SSA.
\end{abstract}

Keywords: Plasmablastic lymphoma, HIV, EBV, EPOCH, Sub-Saharan Africa

\section{Introduction}

Plasmablastic lymphoma (PBL) is an aggressive non-Hodgkin lymphoma (NHL) subtype associated with human immunodeficiency virus (HIV) infection [1], constituting $2 \%$ of all HIV-associated lymphomas [2]. Despite strong association with HIV, PBL is also seen in HIV-negative patients [3, 4]. Epstein-Barr virus (EBV) increases plasmablasts in blood and lymph nodes in the presence or absence of HIV, and may play a direct role in PBL development [5].

Despite high prevalence of HIV infection in sub-Saharan Africa (SSA), PBL descriptions from the region are scarce. We describe characteristics, treatment, and outcomes of PBL patients enrolled in a prospective, observational cohort in Malawi. This is among the first detailed clinical descriptions of this unique and aggressive NHL subtype from SSA, where HIV and EBV are endemic.

\section{Methods}

We identified patients with PBL enrolled in the prospective Kamuzu Central Hospital Lymphoma Study between May 2013 and May 2017 in Lilongwe, Malawi. PBL diagnoses were histologically and immunophenotypically

\footnotetext{
* Correspondence: satish_gopal@med.unc.edu

1 UNC Project-Malawi, Private Bag, A-104 Lilongwe, Malawi

${ }^{2}$ University of North Carolina, Chapel Hill, USA

Full list of author information is available at the end of the article
}

confirmed, and underwent subsequent secondary review in the United States [6]. All cases were positive for CD138 and negative for CD20 with Ki67 > 90\%.

Following diagnosis, all patients underwent standardized clinical, laboratory, and radiologic assessments as previously described [7]. Before August 2016, patients were treated with CHOP (cyclophosphamide $750 \mathrm{mg} / \mathrm{m}^{2}$, doxorubicin $50 \mathrm{mg} / \mathrm{m}^{2}$, vincristine $1.4 \mathrm{mg} / \mathrm{m}^{2}$ day 1 , and prednisone $40 \mathrm{mg} / \mathrm{m}^{2}$ days 1-5; 21 day cycles). After August 2016, patients received a modified EPOCH regimen (etoposide $50 \mathrm{mg} / \mathrm{m}^{2}$, vincristine $0.4 \mathrm{mg} / \mathrm{m}^{2}$, and doxorubicin $10 \mathrm{mg} / \mathrm{m}^{2}$ days $1-4$, prednisone $60 \mathrm{mg} / \mathrm{m}^{2}$ days $1-5$, and cyclophosphamide $750 \mathrm{mg} / \mathrm{m}^{2}$ day $1 ; 21$-day cycles). Because the local clinical environment does not allow safe administration of 24-h continuous infusions, 24-h doses of etoposide, vincristine, and doxorubicin were instead administered over $6-8 \mathrm{~h}$ on successive days. Hematopoietic growth factors were not available. All HIV-infected patients received antiretroviral therapy (ART) concurrent with chemotherapy.

Cohort characteristics were summarized using simple descriptive statistics. Patients were followed until death or administrative censoring on September 30, 2017. Adverse events were reported using National Cancer Institute Common Terminology Criteria for Adverse Events version 4.0. Kaplan-Meier methods were used to estimate overall survival (OS). Analyses were conducted using Stata version 14.1 (College Station, Texas). 


\section{Results}

Of 183 adults with pathologically confirmed NHL during the study period, we identified 12 patients with PBL (Table 1). Median age was 46 years (range 26-71), seven (58\%) were male, and six (50\%) were HIV-positive. Of HIV-positive patients, three were diagnosed with HIV prior to PBL diagnosis, and had been on ART for 6, 10, and 14 months. Among HIV-positive patients, median CD4 cell count was $147 \mathrm{cell} / \mu \mathrm{L}$ (range 9-460) and three (50\%) had suppressed HIV RNA $<400$ copies $/ \mathrm{mL}$ at PBL diagnosis. Of seven patients whose tumors were tested for EBV-encoded RNA (EBER) by in situ hybridization, five (71\%) were positive: $3 / 3$ HIV-positive, $2 / 4$ HIV-negative. All patients had a primary site of disease in the head and neck. Nine (75\%) patients had Ann Arbor stage I/II disease. Median lactate dehydrogenase was 339 IU/L (range 186-2522 IU/L, upper limit of normal $250 \mathrm{IU} / \mathrm{L}$ ).

Eight patients were treated with $\mathrm{CHOP}$ for a median of six cycles (range 1-8). Four patients received the modified EPOCH regimen for a median of five cycles (range 2-6). All patients receiving EPOCH and 50\% of $\mathrm{CHOP}$ recipients experienced treatment delay due to grade 3/4 neutropenia and one $\mathrm{CHOP}$ recipient experienced delay due to grade 3 anemia. Overall, five (42\%) patients achieved a complete response (CR) after chemotherapy [CHOP 2/8 (25\%); EPOCH 3/4 (75\%)]. Both patients who achieved $\mathrm{CR}$ after $\mathrm{CHOP}$ relapsed 4 months after treatment completion.
As of September 30, 2017, vital status was known for all patients and median follow-up was 13 months (range 1-35) among patients still alive. One-year OS was 56\% (95\% CI 24-79\%, Fig. 1). No differences were observed between HIV-positive patients (1-year OS 67, 95\% CI 19-90\%) and HIV-negative patients (1-year OS 42, 95\% CI $6-77 \%, p=0.53)$. Of seven deaths, one was due to neutropenic sepsis and six due to lymphoma progression.

\section{Discussion}

In resource-rich settings, $\mathrm{PBL}$ is a rare lymphoma subtype with poor outcomes $[8,9]$. The current National Comprehensive Cancer Network guidelines recommend intensive chemotherapy regimens such as dose-adjusted EPOCH, hyper-CVAD (cyclophosphamide, vincristine, doxorubicin, dexamethasone alternating with cytarabine, methotrexate), or CODOX-M/IVAC (cyclophosphamide, vincristine, doxorubicin, methotrexate alternating with ifosfamide, etoposide, cytarabine). Consolidative high-dose chemotherapy and autologous stem cell rescue in first remission is also recommended by some [10]. Ongoing studies in high-income countries are attempting to investigate anti-myeloma agents (bortezomib, daratumumab, etc.) added to aggressive NHL chemotherapy regimens to improve outcomes, based on plasmacytic differentiation of PBL tumor cells $[11,12]$. Conversely, other studies have demonstrated similar or worse results after intensive chemotherapy regimens compared with $\mathrm{CHOP}$ due to excess treatment-related complications [10, 13].

Table 1 Baseline characteristics of plasmablastic lymphoma patients from the Kamuzu Central Hospital Lymphoma Cohort study

\begin{tabular}{|c|c|c|c|}
\hline & Total $(n=12)$ & $\mathrm{HIV}+(n=6)$ & HIV- $(n=6)$ \\
\hline Age, years, median (range) & $46(26-71)$ & $39(30-60)$ & $53(26-71)$ \\
\hline Male sex, n (\%) & $7(58)$ & $2(33)$ & $5(83)$ \\
\hline Largest tumor location head and neck, n (\%) & $12(100)$ & $6(100)$ & $6(100)$ \\
\hline CNS involvement, n (\%) & $1(8)$ & $0(0)$ & $1(17)$ \\
\hline Bone marrow involvement, $\mathrm{n}(\%)$ & $3(25)$ & $2(33)$ & $1(17)$ \\
\hline Largest diameter of mass, cm, median (range) & $10(3-22)$ & $8(3-15)$ & $11(10-22)$ \\
\hline Ann Arbor stage I/II, n (\%) & $9(75)$ & $6(100)$ & $3(50)$ \\
\hline Performance score $\geq 2, \mathrm{n}$ (\%) & $1(8)$ & $0(0)$ & $1(17)$ \\
\hline White blood cells, $10^{3} / \mathrm{uL}$, median (range) & $4.6(2.7-14.9)$ & $11.6(6.2-12.5)$ & $6.1(2.7-14.9)$ \\
\hline Absolute neutrophils, $10^{3} / \mathrm{uL}$, median (range) & $2.74(0.92-10.6)$ & $2.55(0.9-4.07)$ & $2.48(1.3-10.6)$ \\
\hline Hemoglobin, g/dL, median (range) & $11(6.2-14.9)$ & $11.6(6.2-12.5)$ & $10.9(10.1-14.9)$ \\
\hline Platelets, $10^{3} / \mathrm{uL}$, median (range) & $206(103-666)$ & $210(176-666)$ & $233(103-458)$ \\
\hline Lactate dehydrogenase $(\mathrm{LDH}), \mathrm{IU} / \mathrm{L}$, median $(\text { range })^{\mathrm{a}}$ & $338(186-2522)$ & $328(240-2522)$ & $226(186-1803)$ \\
\hline CD4 count, cells/ $\mu \mathrm{L}$, median (range) & - & $147(9-460)$ & - \\
\hline HIV RNA < 400 copies/mL, n (\%) & - & $3(50)$ & - \\
\hline EBER expression n (\%) & $5(71)$ & $3(100)$ & $2(50)$ \\
\hline
\end{tabular}

Abbreviations: CNS Central nervous system, EBV Epstein Barr virus, EBER EBV encoded RNA, ECOG PS Eastern oncology cooperative group performance status, HIV human immunodeficiency virus, $L D H$ lactate dehydrogenase

${ }^{\mathrm{a}} \mathrm{LDH}$ normal range $=0-250 \mathrm{IU} / \mathrm{L}$ 


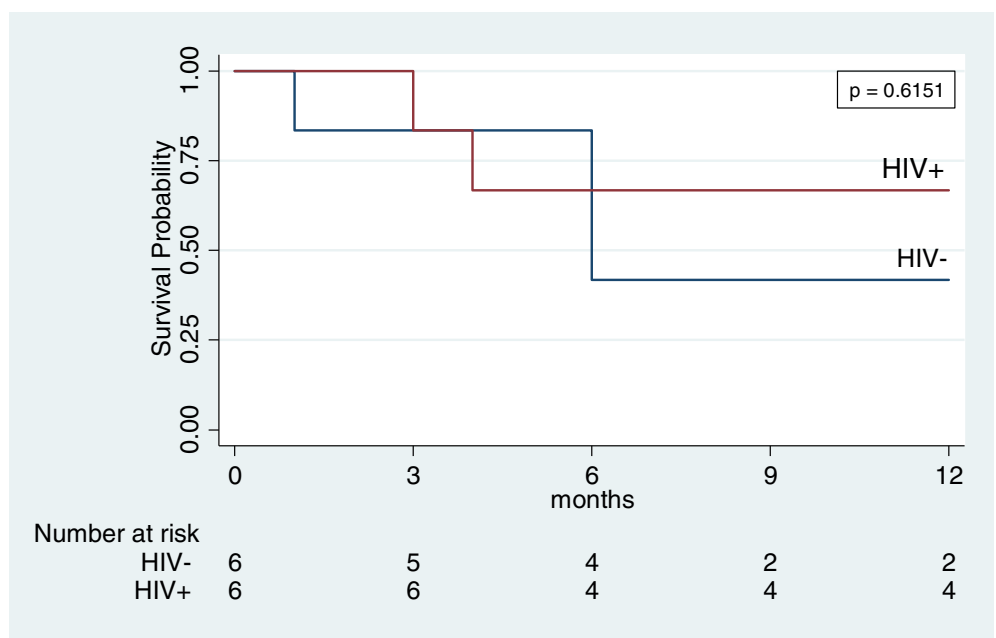

Fig. 1 Overall survival of plasmablastic lymphoma patients in Lilongwe stratified by HIV status. No difference was found between HIV+ and HIVpatients by log-rank test

Upon first recognition of PBL in Malawi, and due to supportive care constraints, we initially treated participants with CHOP resulting in a $25 \%$ CR rate, with nearly all patients dying of progressive disease rather than treatment-related complications. Given these poor outcomes, we intensified our approach to a modified EPOCH regimen adapted as required by clinic infrastructure, resulting in a 75\% CR rate, although follow-up time for this more recently treated group is limited. Nevertheless, this experience illustrates that even in a resource-limited country, sustained investments in cancer diagnostic and treatment capabilities can lead to recognition of new tumor types, foundational understanding of outcomes using standard approaches, and evidence-based adjustment of therapeutic approaches.

HIV-positive and HIV-negative patients with PBL have different clinical and pathologic characteristics, including better response to chemotherapy in HIV-positive patients [14]. HIV-positive PBL patients are younger, predominantly male, and have more frequent oral involvement. HIV-positive PBL cases have significantly higher expression of CD20, CD56, and EBER compared with HIV-negative PBL. HIV-positive patients with PBL have also been reported to have better survival than HIV-negative patients with PBL [14]. We found no difference in OS between HIV-positive and HIV-negative patients, although our sample size is small and trends in OS by HIV status were similar to those described in high-income countries.

Previous studies have indicated that PBL is closely associated with EBV infection. A metanalysis of PBL cases demonstrated EBV by in situ hybridization in $75 \%$ of HIV-infected cases and 50\% of HIV-uninfected cases [9]. Similarly, our findings confirmed EBV presence in $3 / 3$ HIV-positive cases but only 2/4 HIV-negative cases.
Strengths of our study include its prospective longitudinal nature, no loss to follow-up, standardized treatment, and pathologic confirmation using immunohistochemistry and telepathology consultation, all of which are not common in studies of lymphoproliferative disorders in SSA. Limitations are small sample size and relatively short follow-up. Ongoing enrollment and long-term follow-up will allow better understanding of prognostic factors and outcomes.

In conclusion, PBL occurs in SSA and may be underdiagnosed in many settings. Further study is needed to identify best treatment approaches, but our early experience suggests treatment intensification might lead to better outcomes for this population even in highly resource-limited environments.

\section{Abbreviations}

CD4: Positive for cluster of differentiation 4; CHOP: Cyclophosphamide, doxorubicin, vincristine, and prednisone; EBER: Epstein-Barr virus-encoded RNA; EBV: Epstein Barr virus; EPOCH: Etoposide, prednisone, vincristine, cyclophosphamide and doxorubicin; HIV: Human immunodeficiency virus; OS: Overall survival; PBL: Plasmablastic lymphoma

\section{Acknowledgements}

We wish to thank patients and their families for participating in this study. We also thank Wiza Kumwenda for developing the study database, our pathology team and the University of North Carolina Translational Pathology Laboratory for performing additional stains.

\section{Funding}

This work was supported by grants from the National Institutes of Health (K01TW009488, R21CA180815, and U54CA190152 to S.G.), the Medical Education Partnership Initiative (U2GPS001965), and the Lineberger Comprehensive Cancer Center (P30CA016086).

\section{Availability of data and materials}

The datasets used and/or analysed during the current study are available from the corresponding author on reasonable request. 


\section{Authors' contributions}

TZ performed research, analyzed data, and wrote the manuscript; MSP and RS wrote the manuscript; EK analyzed the data; BK, EK, TT, BMD, MM, MC, BT, SC, AN, FC, CK, RK, NDM, YF performed research; SG designed the study, performed research, and wrote the manuscript. All authors approved the manuscript for submission.

\section{Ethics approval and consent to participate}

All patients provided written informed consent for participation in the Kamuzu Central Hospital Lymphoma Study, which was approved by the Malawi National Health Sciences Research Committee (1107) and University of North Carolina Biomedical Institutional Review Board (12-2255).

\section{Consent for publication}

Not applicable

\section{Competing interests}

The authors declare that they have no competing interests.

\section{Publisher's Note}

Springer Nature remains neutral with regard to jurisdictional claims in published maps and institutional affiliations.

\section{Author details}

'UNC Project-Malawi, Private Bag, A-104 Lilongwe, Malawi. ${ }^{2}$ University of North Carolina, Chapel Hill, USA. ${ }^{3}$ University of Malawi College of Medicine, Blantyre, Malawi. ${ }^{4}$ Kamuzu Central Hospital, Lilongwe, Malawi.

Received: 23 May 2018 Accepted: 22 June 2018

Published online: 28 June 2018

\section{References}

1. STEIN \& H. Plasmablastic lymphoma: WHO Classification of Tumours of Haematopoietic and Lymphoid Tissues; 2008. p. 256-7. https://cinii.ac.jp/ naid/10027382444/ Accessed 8 Feb 2018

2. Carbone A. AIDS-related non-Hodgkin's lymphomas: from pathology and molecular pathogenesis to treatment. Hum Pathol. 2002;33:392-404. http:// www.ncbi.nlm.nih.gov/pubmed/12055673 Accessed 9 Feb 2018

3. Han X, Duan M, Hu L, Zhou D, Zhang W. Plasmablastic lymphoma: review of 60 Chinese cases and prognosis analysis. Medicine. 2017;96:e5981. http:// insights.ovid.com/crossref?an=00005792-201703030-00006 Accessed 7 Feb 2018

4. Choi S-Y, Cho Y-A, Hong S-D, Lee J-I, Hong S-P, Yoon H-J. Plasmablastic lymphoma of the oral cavity in a human immunodeficiency virus-negative patient: a case report with literature review. Oral Surg Oral Med Oral Pathol Oral Radiol. 2014;117:e115-20. http://linkinghub.elsevier.com/retrieve/pii/ S2212440313002216 Accessed 9 Feb 2018

5. Ferrazzo K, Mesquita R, Aburad A, Nunes F, de Sousa S. EBV detection in HIV-related oral plasmablastic lymphoma. Oral Dis. 2007;13:564-9. http:// www.ncbi.nlm.nih.gov/pubmed/17944673 Accessed 7 Feb 2018

6. Tomoka T, Montgomery ND, Powers E, Dhungel BM, Morgan EA, Mulenga M, Gopal S, Fedoriw Y. Lymphoma and pathology in sub-Saharan Africa. Clin Lab Med. 2018;38:91-100. http://www.ncbi.nlm.nih.gov/pubmed/ 29412887 Accessed 23 Feb 2018

7. Gopal S, Fedoriw Y, Kaimila B, Montgomery ND, Kasonkanji E, Moses A Nyasosela R, Mzumara S, Varela C, Chikasema M, Makwakwa V, Itimu S, Tomoka T, Kamiza S, Dhungel BM, Chimzimu F, Kampani C, Krysiak R, Richards KL, Shea TC, et al. CHOP chemotherapy for aggressive nonHodgkin lymphoma with and without HIV in the antiretroviral therapy era in Malawi. PLoS One. 2016;11:e0150445. http://www.ncbi.nlm.nih.gov/ pubmed/26934054 Accessed 8 Feb 2018

8. Loghavi S, Alayed K, Aladily TN, Zuo Z, Ng S-B, Tang G, Hu S, Yin CC, Miranda RN, Medeiros LJ, Khoury JD. Stage, age, and EBV status impact outcomes of plasmablastic lymphoma patients: a clinicopathologic analysis of 61 patients. J Hematol Oncol. 2015;8:65. http://www.ncbi.nlm.nih.gov/ pubmed/26055271 Accessed 8 Feb 2018

9. Morscio J, Dierickx D, Nijs J, Verhoef G, Bittoun E, Vanoeteren X, Wlodarska I, Sagaert X, Tousseyn T. Clinicopathologic comparison of Plasmablastic lymphoma in HIV-positive, immunocompetent, and posttransplant patients. Am J Surg Pathol. 2014;38:875-86. http://www.ncbi.nlm.nih.gov/pubmed/ 24832164 Accessed 8 Feb 2018
10. Castillo JJ, Bibas M, Miranda RN. Review article the biology and treatment of plasmablastic lymphoma. Blood. 2015;125:2323-31.

11. Guerrero-Garcia TA, Mogollon RJ, Castillo JJ. Bortezomib in plasmablastic lymphoma: a glimpse of hope for a hard-to-treat disease. Leuk Res. 2017;62: 12-6. http://www.ncbi.nIm.nih.gov/pubmed/28963907 Accessed 26 Feb 2018

12. Castillo JJ, Reagan JL, Sikov WM, Winer ES. Bortezomib in combination with infusional dose-adjusted EPOCH for the treatment of plasmablastic lymphoma. Br J Haematol. 2015c;169:352-5. http://www.ncbi.nlm.nih.gov/ pubmed/25612847 Accessed Feb 262018

13. Castillo JJ, Reagan JL. Plasmablastic lymphoma: a systematic review. TheScientificWorldJournal. 2011;11:687-96. http://www.ncbi.nlm.nih.gov/ pubmed/21442146 Accessed 8 Feb 2018

14. Castillo JJ, Winer ES, Stachurski D, Perez K, Jabbour M, Milani C, Colvin G, Butera JN. Clinical and pathological differences between human immunodeficiency virus-positive and human immunodeficiency virusnegative patients with plasmablastic lymphoma. Leuk Lymphoma. 2010;51: 2047-53. https://doi.org/10.3109/10428194.2010.516040. Accessed 8 Feb 2018

\section{Ready to submit your research? Choose BMC and benefit from:}

- fast, convenient online submission

- thorough peer review by experienced researchers in your field

- rapid publication on acceptance

- support for research data, including large and complex data types

- gold Open Access which fosters wider collaboration and increased citations

- maximum visibility for your research: over $100 \mathrm{M}$ website views per year

At BMC, research is always in progress.

Learn more biomedcentral.com/submissions 